\title{
Usporedba hrvatskih i slovenskih vikendaških kretanja na hrvatskim otocima: primjer općine Dobrinj
}

DOI: $10.11567 / \mathrm{met} .29 .2 .6$

UDK: $379.834(497.5)(210-7 \mathrm{Krk}=163.42=163.6)$

316.334.52:728.71](497.5)(210-7 Krk=163.42=163.6)

Izvorni znanstveni rad

Primljeno: 2.11.2013.

Prihvaćeno: 3.12.2013.

\section{Vuk Tvrtko Opačić}

Geografski odsjek, Prirodoslovno-matematički fakultet Sveučilišta u Zagrebu, Zagreb vtopacic@geog.pmf.hr

\begin{abstract}
SAŽETAK
Zbog blizine i prometne dostupnosti slovenski vlasnici stanova za odmor i rekreaciju, najzastupljeniji inozemni vikendaši u Hrvatskoj, tradicionalno su najbrojniji na prostoru Istre i Kvarnera. Njihovom brojnošću među kvarnerskim otocima ponajviše se ističe otok Krk. Glavni cilj ovoga rada jest usporediti prostorne i strukturne karakteristike hrvatskih i slovenskih vikendaških kretanja u receptivnome vikendaškom području. Kao reprezentativni primjer receptivnoga vikendaškog područja na hrvatskim otocima s podjednakom zastupljenošću hrvatskih i slovenskih vikendaša izabrana je općina Dobrinj, jedinica lokalne samouprave na otoku Krku s najvećim brojem vlasnika stanova za odmor i rekreaciju iz Slovenije. Istraživanje metodološki počiva na obradbi relevantne literature kao i statističkoj analizi kvantitativnih podataka popisne statistike i podataka Općine Dobrinj o površini stambenih jedinica za odmor i rekreaciju te mjestu stalnoga prebivališta njihovih vlasnika prema regijama NUTS-3: hrvatskim županijama te slovenskim statističkim regijama. Osim metodom deskriptivne statistike razlike između hrvatskog i slovenskog poduzorka ispitane su hi-kvadrat testom i t-testom. Istraživanjem su se kao vodeća emitivna područja u Hrvatskoj izdvojili Grad Zagreb, Primorsko-goranska županija te Zagrebačka županija, a u Sloveniji Središnja Slovenija i Savinjska regija. Zaključeno je da nema izraženije razlike u preferiranju obalnih naselja, odnosno naselja u unutrašnjosti između hrvatskih i slovenskih vikendaša, da nema značajnije razlike u površini »hrvatskih « i »slovenskih « vikendica, da hrvatski vikendaši u odnosu na slovenske žive u emitivnim naseljima bližim receptivnim naseljima u općini Dobrinj, da su naselja stalnih prebivališta hrvatskih vikendaša u prosjeku veća od naselja stalnih prebivališta slovenskih vikendaša te da je naglašenija dominacija Grada Zagreba i Zagrebačke županije, kao vodećega emitivnog područja u kontingentu hrvatskih vikendaša, nego Središnje Slovenije (s Ljubljanom) kod slovenskih.
\end{abstract}

KLJUČNE RIJEČI: vikendaštvo, međunarodna vikendaška kretanja, rekreacija, općina Dobrinj, otok Krk, Hrvatska 


\section{UVOD}

Značenje i uloga vikendica u postmodernističkome društvu promijenili su se usporedo s promjenom prirode čovjekove mobilnosti. Intenziviranje mobilnosti između prvoga i drugoga doma samo je jedan primjer kako kretanje postaje uobičajeni dio svakodnevnoga života. Usporedo s razvojem sve mobilnijega društva, u kojemu je kretanje jedna od osnovnih odrednica, među stranim i domaćim znanstvenicima razvila se široka rasprava o promjeni tradicionalnih definicija pojma migracija te o njezinim sastavnicama (Bell i Ward, 2000; Williams i Hall, 2000a, 2000b; Božić, 2001; Nejašmić, 2005, 2008). Danas naime cirkulacija između stalnoga prebivališta i vikendice ${ }^{1}$ ne znači odvajanje od uobičajenoga načina života, nego normalni dio suvremenoga životnog stila (»putujuće čovječanstvo«), što upućuje na činjenicu da su nam putovanja, tj. cirkulacija, postala svakodnevica (Williams i dr., 2000; Williams i Kaltenborn, 2001). Turistička i vikendaška kretanja dio su migracija, odnosno cirkulacija, koje uključuju raznolike oblike prostornih kretanja - od turističkih putovanja do promjene stalnoga prebivališta (Bell i Ward, 2000; Williams i Hall, 2000a, 2000b; Opačić, 2012). Glavnina autora priklonila se mišljenju da se vikendaštvo ${ }^{2}$ treba promatrati u kontekstu dugoročne cirkulacije, što zbog jače privrženosti mjestu (place attachment) dovodi do sezonskih migracija, a ponekad i do konačnoga, trajnog preseljenja (npr. umirovljenička migracija) (Müller, 2002; Casado-Diaz, 2004). Tako se u oblike cirkulacije mogu uvrstiti jednodnevni posjeti vikendicama nakon posla (dnevna vikendaška cirkulacija) te boravci u vikendicama vikendima i kraćim praznicima (tjedna vikendaška cirkulacija), dok se zbog elemenata (sezonske) promjene boravišta, dakle (sekundarnog) stanovanja kao oblici migracije mogu prepoznati boravci u vikendicama za dužih praznika (sezonska vikendaška migracija), boravci u većem dijelu godine (višemjesečna/polugodišnja migracija) te eventualno preseljenje u vikendice (konačna migracija) (Opačić, 2011, 2012).

Pod pojmom vikendica u ovome radu podrazumijevaju se sve stambene jedinice za odmor i rekreaciju/ sekundarno stanovanje koje se pojavljuju u obliku kuće i stana, koje se rabe bilo vikendima i kraćim praznicima, bilo za duže boravke te koje služe bilo za odmor i rekreaciju, bilo za komercijalne svrhe. Znači, u ovom radu pojam vikendica neće se odnositi na vrstu objekta prema morfološkim karakteristikama, nego na njegovu rekreacijsku funkciju, bez obzira na to je li riječ o stambenoj jedinici u obliku kuće ili u obliku stana (apartmana).

2 Tražeći prikladan izraz koji bi jednom riječju obuhvatio fenomen sekundarnoga rekreacijskog stanovanja kao opća imenica, došlo se do zaključka da takva izraza u rječnicima hrvatskoga jezika nema. Čini se da bi pojam vikendaštvo mogao kvalitetno nadomjestiti taj manjak jer je već pri prvom susretu razumljiv i jasan, a istodobno prati tvorbenu tradiciju hrvatskoga jezika. Pod pojmom vikendaštvo razumijeva se fenomen vikendica (stambenih jedinica za odmor i rekreaciju), tj. fenomen sekundarnoga stanovanja. Može označivati vikendice kao raširenu pojavu te organiziranu djelatnost/aktivnost vikendaša, odnosno ukupnost svih pojava i procesa povezanih s pojmovima vikendica, objekt za odmor i rekreaciju, drugi dom te sekundarno (povremeno) stanovanje (Opačić, 2011, 2012). 
U Hrvatskoj se prelaskom na tržišnu ekonomiju u posljednjih dvadesetak godina postupno ustrojilo tržište nekretnina. Ono se snažnije počinje razvijati tek u drugoj polovini 90-ih godina 20. stoljeća pošto je privatizirana većina stanova i poslovnih prostora naslijeđenih iz socijalizma (Mihaljek, 2005). Postojanje organiziranoga tržišta nekretnina koje posluje po definiranim i uhodanim pravilima danas je jedan od preduvjeta i čimbenika izraženije vikendaške potražnje.

Usporedo s revitalizacijom hrvatskoga turizma nakon smirivanja ratnih prilika, i kod stranaca se javio interes ne samo za turistički boravak nego i za kupnju vikendica u Hrvatskoj. Novooformljeno hrvatsko tržište nekretnina osobito je potaknulo stranu vikendašku potražnju, koja je do početka svjetske recesije prije nekoliko godina jačala iz godine u godinu, ponajviše na hrvatskoj obali i na otocima (Opačić, 2012).

Vlasnici stanova za odmor i rekreaciju iz Slovenije zauzimaju vodeće mjesto u strukturi inozemnih vikendaša u hrvatskom priobalju (Opačić, 2012). Najveći broj tih vlasništava datira iz razdoblja bivše Jugoslavije, kada je svaki njezin građanin pod ravnopravnim uvjetima mogao kupiti nekretninu u bilo kojoj republici. Razumljivo je da je državljanima obližnje Slovenije priobalni dio Hrvatske bio i ostao osobito zanimljiv, kako za turistički boravak tako i kao lokaciju stanova za odmor i rekreaciju (Curić, 2002). Zbog blizine i prometne dostupnosti slovenski vikendaši tradicionalno su zastupljeniji u strukturi vlasnika vikendica na prostoru Istre i Kvarnera, pri čemu se među kvarnerskim otocima ponajviše ističe Krk (Opačić, 2008). Pojava apartmanizacije, približavanje Hrvatske Europskoj uniji te konačni ulazak Hrvatske u njezino punopravno članstvo uvelike su umanjili administrativne prepreke stranim državljanima prilikom stjecanja nekretnine $\mathrm{u}$ Hrvatskoj te tako osnažili »novi val« međunarodnoga, ponajprije slovenskog, vikendaštva na Krku.

\section{CILJ,METODOLOGIJA I PROSTORNI OKVIR ISTRAŽIVANJA}

Prilikom istraživanja vikendaških kretanja, kao segmenta koncepta istraživanja vikendaštva u receptivnome vikendaškome području, neophodno je detaljno analizirati: a) sociodemografske karakteristike vikendaške populacije (dob, spol, stupanj obrazovanja, materijalni status itd.), b) učestalost upotrebe vikendice i duljinu boravka $u$ vikendici te c) prostorne relacije vikendaških kretanja (smjerove i intenzitet vikendaške prostorne pokretlji- 
vosti između emitivnih i receptivnih vikendaških područja) (Opačić, 2011).

Budući da su međunarodna vikendaška kretanja sve izraženija pojava u sekundarnome rekreacijskom stanovanju na hrvatskoj obali i otocima, čini se da je opravdano zapitati se jesu li njihova obilježja istovjetna s »klasičnim « karakteristikama vikendaštva ili se pak prostorna i strukturna obilježja »novoga vala« vikendaških kretanja u priobalnome dijelu Hrvatske uvelike razlikuju od prethodne razvojne faze u kojoj je prevladavalo domaće vikendaštvo. Iz tako definirane svrhe istraživanja kao glavni cilj ovoga rada nameće se usporedba prostornih i strukturnih karakteristika hrvatskih i slovenskih vikendaških kretanja u receptivnome vikendaškom području.

Kao reprezentativni primjer receptivnoga vikendaškog područja na hrvatskim otocima s podjednakom zastupljenošću hrvatskih i slovenskih vikendaša izabrana je općina Dobrinj na otoku Krku (slika 1). Riječ je o jedinici lokalne samouprave na otoku s tradicionalno najvećim brojem vlasnika stanova za odmor i rekreaciju iz Slovenije. 
Slika 1. Administrativno-teritorijalno ustrojstvo otoka Krka; podjela općine Dobrinj po naseljima; 1 - sjedište općine/grada; 2 - granica općine/grada, 3 - granica naselja općine Dobrinj

Figure 1. Administative-territorial organisation of the island of Krk; division of the Municipality of Dobrinj according to settlements; 1 - the municipality/town seat, 2 - the municipality/town border, 3 - the Municipality of Dobrinj border




U ostvarivanju istaknutog cilja istraživanja potrebno je ispitati sljedeće radne hipoteze:

1. Hrvatski vikendaši naglašenije su koncentrirani u obalnim naseljima od slovenskih.

2. Stambene jedinice za odmor i rekreaciju u vlasništvu hrvatskih vikendaša u prosjeku su veće od onih u vlasništvu slovenskih vikendaša.

3. Hrvatski vikendaši u odnosu na slovenske žive u prosjeku u emitivnim naseljima bližim receptivnim naseljima u općini Dobrinj.

4. Naselja stalnih prebivališta hrvatskih vikendaša u prosjeku su veća od naselja stalnih prebivališta slovenskih vikendaša.

5. Naglašenija je dominacija Grada Zagreba i Zagrebačke županije kao vodećega emitivnog područja u kontingentu hrvatskih vikendaša nego Središnje Slovenije (s Ljubljanom) kod slovenskih.

Istraživanje metodološki počiva na obradi relevantne literature i statističkoj analizi kvantitativnih podataka demografske statistike iz 2011. u Hrvatskoj te 2013. u Sloveniji (Popis stanovništva, kućanstava i stanova 2011. godine, 2013; Prebivalstvo - izbrani kazalniki, naselja, Slovenija, letno, 2013), kao i podataka Općine Dobrinj iz travnja 2001., ožujka 2007. te lipnja 2013. o površini stambenih jedinica za odmor i rekreaciju te mjestu stalnoga prebivališta njihovih vlasnika prema hrvatskim županijama, odnosno slovenskim statističkim regijama (razina NUTS-3).

U istraživanju je primijenjena strategija prigodnoga uzorkovanja koja se temelji na upotrebi statističkih podataka evidencije Općine Dobrinj. Iako je upotrijebljena cjelovita općinska evidencija vikendaša, ona se ne može izjednačiti s čitavom populacijom hrvatskih i slovenskih vlasnika vikendica u općini Dobrinj zbog: a) nepoklapanja podataka o broju stambenih jedinica za odmor i rekreaciju općinske evidencije i popisne statistike $2011 .{ }^{3}$ b) namjernoga izostavljanja iz analize vikendica čiji vlasnici kao mjesto stalnog prebivališta navode naselja na otoku Krku, jer je malo vjerojatno da se taj dio stambenoga fonda uistinu rabi u svrhu povremenoga rekreacijskog stanovanja te c) mogućnosti da isti vlasnik posjeduje više stambenih jedinica za odmor i rekreaciju u općini Dobrinj. Analogno tome općinska evidencija može poslužiti kao temelj uzorkovanja, ali ne i kao potpuni uvid u cjelovitu populaciju vikendaša.

3 Prema popisnim podacima, u općini Dobrinj 2011. evidentirana su 2844 stana za odmor i rekreaciju, dok je u općinskoj dokumentaciji u lipnju 2013. bio registriran 1781. Osim bespravne gradnje, koja u općini Dobrinj nije uzela većeg maha (Opačić, 2012), razlozi leže i u teškom razlučivanju stalnog stanovanja od povremenoga rekreacijskog stanovanja, jer je ono najčešće rezultat izbora vlasnika koji objekt prijavljuje. Naime dio vlasnika vikendica u općini, osobito onih koji žive u Rijeci i ostalim naseljima Primorsko-goranske županije, kao adresu stalnoga prebivališta navodi onu na Krku, između ostaloga radi ostvarivanja prava na besplatni prijelaz preko Krčkoga mosta. 
Osim deskriptivne statistike podataka o ukupnom kontingentu vikendaša u općini Dobrinj iz lipnja 2013., za utvrđivanje razlika između hrvatskih i slovenskih vikendaških kretanja koriste se hi-kvadrat test i t-test. Najkraća kilometarska cestovna udaljenost između naselja stalnog prebivališta vlasnika vikendice i receptivnog naselja u općini Dobrinj izračunata je pomoću mrežne stranice Google Maps.

\section{GEOGRAFSKA OBILJEŽJA OPĆINE DOBRINJ KAO ČIMBENIK POJAVE I RAZVOJA VIKENDAŠTVA}

Flišna zona mikroregionalne cjeline Srednjega Krka, u kojoj su koncentrirane najvrednije poljoprivredne zone na otoku (Novosel-Žic, 1987), uvelike je u prošlosti određivala gospodarsku bazu općine Dobrinj (Opačić, 2002). Ipak, poljoprivreda temeljena na vrlo ograničenim agrarnim potencijalima (relativno plitak sloj obradivog tla, usitnjeni zemljišni posjed, male površine na kršu itd.) stanovništvu Dobrinjštine u prošlosti je osiguravala tek puko preživljavanje, stoga se u uvjetima prometne izoliranosti i nedostatno razvijenih grana sekundarnih i tercijarnih djelatnosti već nakon Prvoga svjetskog rata javlja emigracijom uvjetovana depopulacija kao glavni demografski proces u općini (Novosel-Žic, 1996; Opačić, 2002). Evidentan je i problem usitnjene naseljenosti, što je nepovoljno za razvoj uslužnih djelatnosti. Na prostoru općine u kojoj je prema popisu stanovništva 2011. živjelo 2078 stanovnika razvilo se čak devetnaest stalno nastanjenih malih naselja (jedno, Dolovo, izumrlo je), prosječne veličine od samo 109,4 stanovnika 2011. godine. Dinamičniji gospodarski razvoj usporava i nepovoljna dobna struktura stanovništva. Naime više od trećine ukupne populacije (2011. godine $33,8 \%$ ) čini staro stanovništvo (stariji od 60 godina). Glavnina stalno nastanjenih naselja u općini nalazi se u unutrašnjosti otoka (petnaest), dok je samo pet naselja (Čižići, Klimno, Rudine, Soline i Šilo) smješteno uz more, što je u današnjim uvjetima razvoja također nedostatak (Opačić, 2002). ${ }^{4}$ Jedna od kočnica dinamičnijega gospodarskog razvoja općine Dobrinj jest i relativno nedovoljna prometna povezanost i dostupnost, osobito javnim autobusnim prijevozom, kako u odnosu na glavnu otočnu prometnicu Krčki most - Omišalj - Krk - Baška tako i prema Crikveničko-vinodolskom primorju, s kojim su oslabjele veze ukidanjem trajektne linije Šilo - Crikvenica 1992. (Turk i Mirković, 1993; Opačić, 2002, 2012).

Čižići i Soline izvorno su bila naselja u unutrašnjosti jer su im jezgre oko kilometar udaljene od mora, ali su se s ekspanzijom turizma približili moru, pa ih se danas ubraja u obalna naselja. U kontekstu vikendaštva i naselje Rudine opravdano je klasificirati kao obalno naselje jer se najbliža plaža kao ključni rekreacijski čimbenik nalazi na pješačkoj udaljenosti od nekoliko minuta hoda (Opačić, 2002, 2012). 
Glavne su atrakcijske prednosti općine Dobrinj za pojavu i razvoj vikendaštva postojanje pet obalnih naselja, očuvani tradicionalni ruralni ambijent naselja u šumovitoj, reljefno dinamičnoj unutrašnjosti u blizini morske obale te atraktivna, mala, ambijentalna jezgra Dobrinja, srednjovjekovnoga kaštela (Zelić, 1993), općinskoga sjedišta na dominantnoj, strmoj litici dvjestotinjak metara iznad morske razine. Osobito značenje u turističkoj, ali i vikendaškoj valorizaciji općine ima obala. Krajnji sjeveroistočni dio općine Dobrinj izbija na more slabije pristupačnom, »negostoljubivom « vapnenačkom obalom između uvala Slivanjske i Lončarice, nepovoljnom za turističko-vikendaško vrednovanje. Duboko uvučeni, plitki zaljev Soline (od tri do sedam metara dubine) potopljeni je nastavak središnje flišne zone, a ističe se pristupačnim obalama, pogodnim za turističko-vikendašku valorizaciju, te pješčanim dnom. U uvali Stipanji smješteno je Šilo, najveće općinsko naselje, ujedno i vodeće turističko mjesto u općini. Ovdje se zbog kontakta vapnenca i fliša duž obale naizmjenično redaju šljunčane i pješčane plaže, što je važan privlačni čimbenik za turiste i vikendaše (Opačić, 2002).

Razmjerno veliki broj stanova za odmor i rekreaciju na području današnje općine Dobrinj još prije četrdesetak godina rezultat je postojanja obilja emigracijom ispražnjenoga stambenog fonda (Novosel-Žic, 1980-1981, 1996) i ranog otvaranja tog dijela otoka prema kontinentu, tj. Crikveničkovinodolskom primorju, nakon trajektnoga povezivanja Crikvenice i Šila (još 1959.), kojim je dobrinjsko područje do uspostave kraće i frekventnije, a za korisnike jeftinije, trajektne linije (Črišnjeva - Voz, 1964.) uživalo u prednostima položaja »ulaznih vrata« otoka (Novosel-Žic, 1987; Opačić, 2012).

Na području Dobrinjštine već su se tada kao dvije najizrazitije zone vikendaštva izdvojili najveće općinsko naselje Šilo i priobalni pojas zaljeva Soline. Rana afirmacija Šila kao izletišta crikveničkih turista (Novosel-Žic, 1987) te funkcije ulaznih vrata otoka između 1959. i 1964., potaknula je i prvi val vikendaške potražnje prema tom dijelu otoka. Iako je turizam na području općine Dobrinj dugo bio orijentiran gotovo jedino na privatni smještaj, vikendaštvo se razvijalo podjednako brzo kao i u drugim receptivnim vikendaškim područjima na otoku. I Šilo, kao i naselja uz zaljev Soline, proživjeloje sve etape razvojnoga puta vikendaštva - od prenamjene i adaptacije ispražnjenoga dijela stambenoga fonda preko namjenske izgradnje individualnih obiteljskih vikendica do pojave višestambenih apartmanskih objekata u posljednjih desetak godina (Opačić, 2008, 2009b, 2012). Zabrinjava nagla apartmanizacija u naseljima uz plitak, zatvoren i za prekomjernu (vikendašku) izgradnju posve nepogodan zaljev Soline. Naime osim teških fizionomskih implikacija pojačana apartmanska izgradnja, karakteristična 
za posljednjih desetak godina, ondje može prouzročiti i opasne ekološke probleme.

Pojačana vikendaška potražnja počela je još u 80-im godinama 20. stoljeća, kada osim hrvatskih i brojni slovenski vikendaši podižu uglavnom obiteljske kuće za odmor na prostoru Dobrinjštine. Ta se potražnja, uz kraći zastoj tijekom agresije na Hrvatsku početkom devedesetih i posljednjih godina u uvjetima svjetske gospodarske recesije, nastavila do danas (tablica $1)$.

Tablica 1. Broj vikendica u naseljima općine Dobrinj 2007. i 2013.

Table 1. The number of second homes in the settlements of the Municipality of Dobrinj in 2007 and 2013

\begin{tabular}{|c|c|c|c|}
\hline Naselje & 2007. & 2013. & $\begin{array}{c}\text { Indeks } \\
\text { promjene } \\
\text { 2013./2007. }\end{array}$ \\
\hline Čižići & 157 & 322 & 205,10 \\
\hline Klimno & 126 & 331 & 262,70 \\
\hline Rudine & 8 & 8 & 100,00 \\
\hline Soline & 51 & 131 & 256,86 \\
\hline Šilo & 198 & 318 & 160,61 \\
\hline Obalna naselja & 540 & 1110 & 205,56 \\
\hline Dobrinj & 67 & 69 & 102,99 \\
\hline Gabonjin & 37 & 39 & 105,41 \\
\hline Gostinjac & 33 & 41 & 124,24 \\
\hline Hlapa & 115 & 130 & 113,04 \\
\hline Klanice & 2 & 5 & 250,00 \\
\hline Kras & 50 & 56 & 112,00 \\
\hline Polje & 156 & 173 & 110,90 \\
\hline Rasopasno & 28 & 44 & 157,14 \\
\hline Sužan & 10 & 19 & 190,00 \\
\hline Sv. Ivan Dobrinjski & 7 & 7 & 100,00 \\
\hline Sv. Vid Dobrinjski & 15 & 13 & 86,87 \\
\hline Tribulje & 7 & 5 & 71,43 \\
\hline Žestilac & 43 & 50 & 116,28 \\
\hline Županje & 22 & 20 & 90,91 \\
\hline Naselja u unutrašnjosti & 592 & 671 & 113,34 \\
\hline UKUPNO & 1132 & 1781 & 157,33 \\
\hline
\end{tabular}

Izvor: dokumentacija Općine Dobrinj, 2007. i 2013. 
Razlog recentnoga porasta broja stambenih jedinica za odmor i rekreaciju od čak 57,3\% (indeks promjene broja ${ }^{5}$ vikendica između 2007. i 2013. iznosi čak 157,3) ponajprije leži u snažnoj apartmanizaciji u naseljima uz obalu zaljeva Soline (Klimno - indeks promjene 262,70; Soline - 256,86, Čižići - 205,10), ali i u Šilu $(160,61)$. Obalna naselja zabilježila su veće povećanje broja vikendica u promatranom razdoblju (indeks promjene 205,56) od naselja u unutrašnjosti $(113,34)$, premda je i u nekima od njih lociranima bliže obali, primjerice u Polju i Rasopasnome, proces apartmanizacije počeo u prvim godinama 21. stoljeća (Opačić, 2012). Težište vikendaštva time se iz naselja u unutrašnjosti (592 stambene jedinice za odmor i rekreaciju 2007. prema $540 \mathrm{u}$ obalnim naseljima) u samo šest godina značajno preselilo u obalna naselja (1110 vikendica 2013. u odnosu na 671 vikendicu u naseljima u unutrašnjosti iste godine - 62,3\% svih stambenih jedinica za odmor i rekreaciju u općini Dobrinj, prema podacima općinske dokumentacije). Među pet vodećih naselja po broju vikendica 2013. čak su četiri obalna (Klimno 331, Čižići 322, Šilo 318 i Soline 131) te jedno u unutrašnjosti - Polje (173).

Za vikendaštvo u općini Dobrinj karakteristična je najveća zastupljenost slovenskih vlasnika vikendica (803 stambene jedinice za odmor i rekreaciju 2013.-45,1\% svih vikendica u općini) među svim jedinicama lokalne samouprave na otoku Krku, koji prema podacima općinske dokumentacije prevladavaju u usporedbi s brojem vikendaša iz Zagreba i okolice (442 stambene jedinice za odmor i rekreaciju 2013.- 24,8\% svih vikendica u općini), tradicionalno najbrojnijim kontingentom vikendaša na otoku s obzirom na emitivno vikendaško područje, te Rijeke i ostalih naselja Primorsko-goranske županije (182 stambene jedinice za odmor i rekreaciju 2013. - 10,2\% svih vikendica u općini) (Opačić, 2008) (slika 2).

Indeks promjene broja vikendica od 2007. do 2013. u općini Dobrinj dobiven je jednostavnim izračunom: broj vikendica 2013. podijeljen je brojem vikendica 2007. i pomnožen brojem sto. 
Slika 2. Broj vlasnika vikendica s područja Slovenije, Grada Zagreba i Zagrebačke županije te Primorsko-goranske županije u općini Dobrinj 2001., 2007. i 2013.

Figure 2. The number of second homes owners from Slovenia, the City of Zagreb and the Zagreb County, and the Primorje-Gorski kotar County in the Municipality of Dobrinj in 2001, 2007 and 2013

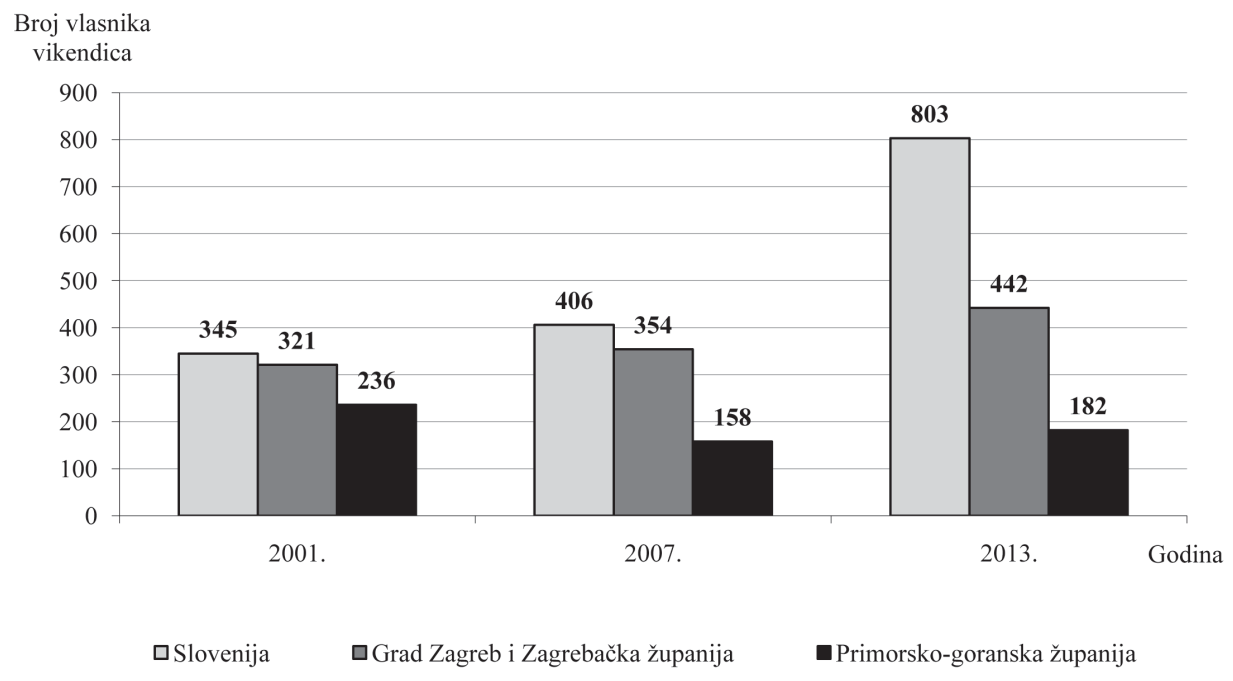

Izvor: dokumentacija Općine Dobrinj, 2001., 2007. i 2013.

Iznadprosječni broj vikendaša sa stalnim prebivalištem u Sloveniji može se objasniti ponajprije ranom prisutnošću radničkih odmarališta slovenskih poduzeća u Šilu, kao i uz zaljev Soline, koja su dijelu korisnika poslužila za stjecanje pozitivna dojma i stvaranje emocionalne povezanosti s prostorom u kojemu su, motivirani time, poslije izgradili kuće za odmor i rekreaciju. Nakon toga neki od njih »povukli« bi za sobom prijatelja iz emitivnoga područja te su tako uspostavljene socijalne mreže pridonijele nastanku pravih »kolonija « slovenskih vikendaša u obalnim, ali i unutrašnjim naseljima Dobrinjštine (Gršković, 2004; Opačić, 2008). Prema riječima Novosel-Žic, o grupiranju vikendaša iz istoga emitivnog vikendaškog područja u receptivnim vikendaškim naseljima otoka Krka, »Slovenci su najbrojniji na dobrinjskom području, posebno u malom unutrašnjem selu Hlapa. Sve napuštene stambene objekte vrlo su rano pokupovali, a sada (70-ih godina 20. stoljeća, op. a.) kupuju ovdje gradilišta« (1980-81: 19). 
U suvremenoj, apartmanskoj fazi razvoja vikendaštva jedan od razloga sve izraženije vikendaške potražnje Slovenaca za nekretninama na Dobrinjštini jest i prisutnost slovenskoga građevinskog poduzeća Slovgrad koje se bavi izgradnjom i prodajom apartmana na tom području, što nesumnjivo dodatno potiče donošenje odluke o kupnji stanova za odmor i rekreaciju kod novih slovenskih vikendaša (Opačić, 2008).

\section{REZULTATI KOMPARATIVNE ANALIZE PROSTORNIH I STRUKTURNIH OBILJEŽJA HRVATSKIH I SLOVENSKIH VIKENDAŠKIH KRETANJA U OPĆINI DOBRINJ}

Od 1781 vikendice evidentirane u dokumentaciji Općine Dobrinj 2013., njih 1645 (92,4\%) u vlasništvu je vikendaša sa stalnim prebivalištem u Hrvatskoj ili Sloveniji. Pritom su hrvatski vikendaši vlasnici 851 stambene jedinice za odmor i rekreaciju, a slovenski njih 803.

Prostorni razmještaj hrvatskih i slovenskih vlasnika vikendica u općini Dobrinj 2013. kao glavna središta hrvatske vikendaške potražnje izdvaja Grad Zagreb, u kojemu žive 342 vlasnika vikendica, Primorsko-goransku županiju (182) te Zagrebačku županiju (100) kao vodeće hrvatske županije te Središnju Sloveniju (370 vlasnika vikendica u općini) i Savinjsku (112) kao dominantne slovenske regije. Kao glavni nosioci vikendaške potražnje u njima ističu se gradovi Zagreb, Rijeka, Ljubljana i Celje sa svojim urbaniziranim okolicama. Značajni broj vlasnika vikendica u općini ima stalno prebivalište i u Karlovačkoj (39) te Varaždinskoj županiji (36), dok u Sloveniji visoko mjesto prema vikendaškoj potražnji drže i Podravska (72 vlasnika vikendica), Jugoistočna Slovenija (67) te Gorenjska (55). Najviše vlasnika iz tih županija/regija živi u najvećim gradovima i okolicama - u Varaždinu i Karlovcu u Hrvatskoj te Mariboru, Novome Mestu i Kranju u Sloveniji (slika 3). 
Slika 3. Broj hrvatskih i slovenskih vlasnika vikendica u općini Dobrinj prema mjestima stalnog prebivališta (hrvatske županije/ slovenske statističke regije) 2013.

Figure 3. The number of Croatian and Slovenian second home owners by the place of permanent residence (Croatian counties/Slovenian statistical regions) in 2013

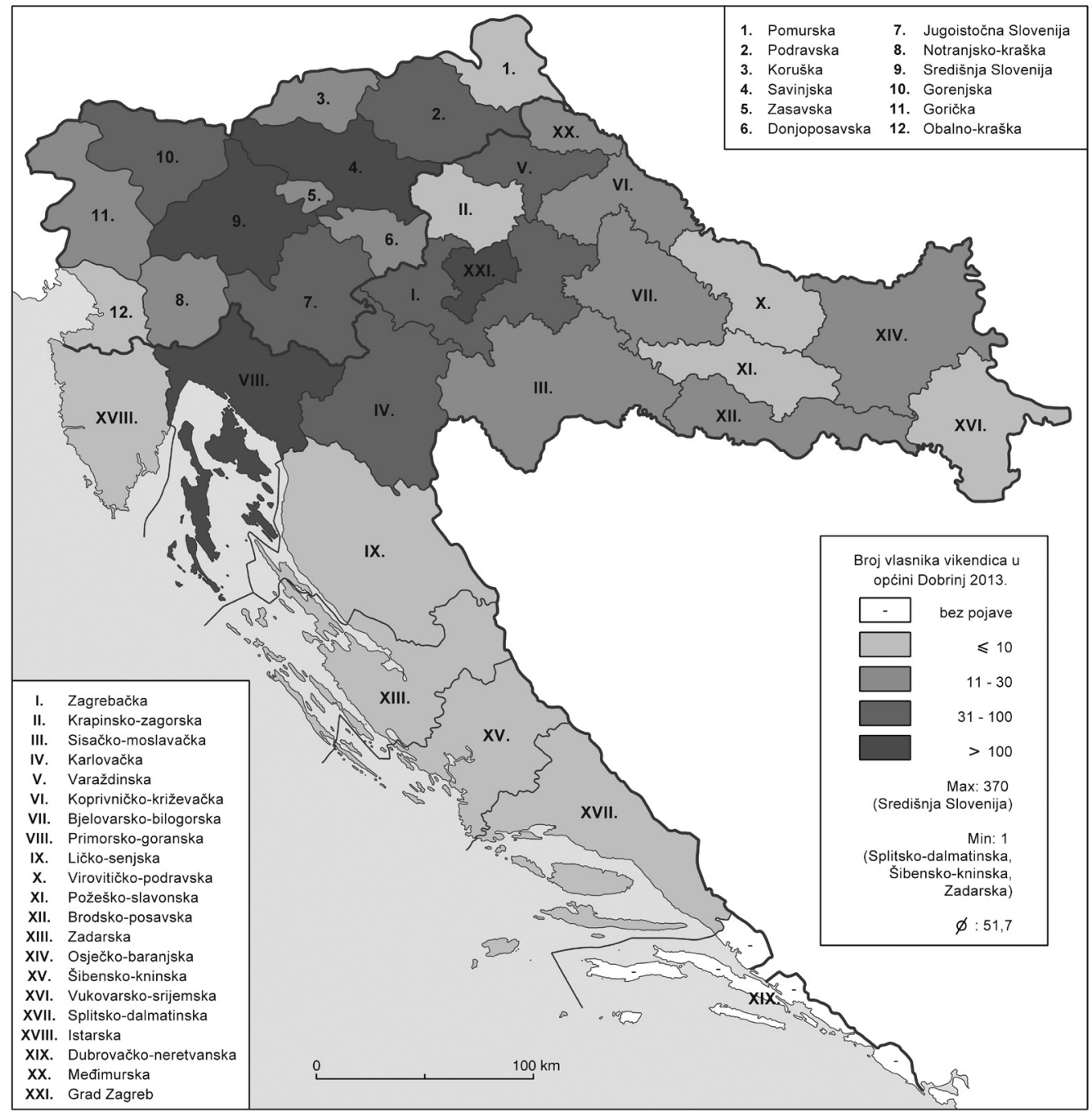

Izvor: dokumentacija Općine Dobrinj, 2013.

Vodeće županije/regije vikendaške potražnje, osobito njihovi najveći gradovi, uglavnom su kvalitetno prometno povezane s otokom Krkom (au- 
toceste) ili su smještene u njegovoj blizini, što omogućuje i veću frekvenciju dolazaka i češću uporabu vikendice. Porastom udaljenosti od Krka očigledno se smanjuje i broj vikendaša - npr. iz Međimurske, Koprivničko-križevačke, Bjelovarsko-bilogorske te Sisačko-moslavačke županije, kao i Pomurske i Koruške regije u Sloveniji. Još manji broj vlasnika stambenih jedinica za odmor i rekreaciju u općini Dobrinj živi u slavonskim županijama. Tek nešto veći broj bilježe Brodsko-posavska i Osječko-baranjska županija zbog postojanja većih urbanih središta (Slavonski Brod, Osijek). Najmanji broj vikendica bilježe pak županije/regije na obali ili u neposrednoj blizini obale, čije stanovništvo svoje vikendaške potrebe zadovoljava u bližim receptivnim vikendaškim područjima, pa je broj vlasnika iz primjerice Istarske, Ličko-senjske, Zadarske i Splitsko-dalmatinske županije u Hrvatskoj, kao i Obalno-kraške, Notranjsko-kraške te Goričke regije malen ili čak zanemariv. Tako je najudaljenija priobalna županija - Dubrovačko-neretvanska županija - jedina analizirana regionalna cjelina u kojoj ne živi nijedan vlasnik vikendice u općini Dobrinj.

U tablici 2 naveden je prostorni razmještaj »hrvatskih« i »slovenskih« vikendica u naseljima općine Dobrinj.

Tablica 2. Broj hrvatskih i slovenskih vlasnika vikendica u naseljima općine Dobrinj 2013.

Table 2. The number of Croatian and Slovenian second home owners in the settlements of the Municipality of Dobrinj in 2013

\begin{tabular}{lccc}
\hline Naselje & $\begin{array}{c}\text { Vlasnici iz } \\
\text { Hrvatske }\end{array}$ & $\begin{array}{c}\text { Vlasnici iz } \\
\text { Slovenije }\end{array}$ & Ukupno \\
\hline Čižići & 122 & 172 & 294 \\
\hline Klimno & 127 & 184 & 311 \\
\hline Rudine & 5 & 3 & 8 \\
\hline Soline & 38 & 79 & 117 \\
\hline Šilo & 232 & 70 & 302 \\
\hline Obalna naselja & $\mathbf{5 2 4}$ & $\mathbf{5 0 8}$ & $\mathbf{1 0 3 2}$ \\
\hline Dobrinj & 60 & 6 & 66 \\
\hline Gabonjin & 28 & 5 & 33 \\
\hline Gostinjac & 20 & 20 & 40 \\
\hline Hlapa & 12 & 111 & 123 \\
\hline Klanice & 4 & 0 & 49 \\
\hline Kras & 47 & 2 & 157 \\
\hline Polje & 84 & 73 & \\
\hline
\end{tabular}




\begin{tabular}{lccc}
\hline Naselje & $\begin{array}{c}\text { Vlasnici iz } \\
\text { Hrvatske }\end{array}$ & $\begin{array}{c}\text { Vlasnici iz } \\
\text { Slovenije }\end{array}$ & Ukupno \\
\hline Rasopasno & 35 & 5 & 40 \\
\hline Sužan & 10 & 8 & 18 \\
\hline Sv. Ivan Dobrinjski & 4 & 2 & 6 \\
\hline Sv. Vid Dobrinjski & 7 & 6 & 13 \\
\hline Tribulje & 2 & 3 & 5 \\
\hline Žestilac & 4 & 45 & 49 \\
\hline Županje & 10 & 9 & $\mathbf{6 2 2}$ \\
\hline Naselja u unutrašnjosti & $\mathbf{3 2 7}$ & $\mathbf{2 9 5}$ & $\mathbf{1 6 5 4}$ \\
\hline UKUPNO & $\mathbf{8 5 1}$ & $\mathbf{8 0 3}$ &
\end{tabular}

Izvor: dokumentacija Općine Dobrinj, 2013.

Hrvatski vlasnici nešto su brojniji i u obalnim naseljima (524 vikendice u vlasništvu vlasnika iz Hrvatske prema 508 iz Slovenije) i u naseljima u unutrašnjosti (327 prema 295), što upućuje na razmjerno ujednačenu distribuciju zastupljenosti s obzirom na obilježja promatranog skupa u cjelini (851 prema 803). Od obalnih naselja hrvatski vikendaši jače su zastupljeni u Šilu, a slovenski u naseljima uz zaljev Soline: Klimnu, Solinama i Čižićima. U naseljima u unutrašnjosti naglašenija prisutnost hrvatskih vikendaša karakteristična je za naselja zapadnoga dijela općine (npr. Rasopasno, Gabonjin i Kras) koja jače gravitira Malinskoj (tradicionalno visoka zastupljenost vikendaša iz Zagreba; Opačić, 2009a, 2012), a slovenskih za naselja u neposrednom zaleđu zaljeva Soline (Hlapa, Žestilac te Polje i Gostinjac - dva naselja s podjednakim brojem »hrvatskih« $i$ »slovenskih « vikendica). U općinskom središtu Dobrinju vikendaši iz Hrvatske u velikoj su većini u odnosu na one iz Slovenije.

Prva radna hipoteza ovoga istraživanja glasi: »Hrvatski vikendaši naglašenije su koncentrirani u obalnim naseljima od slovenskih«, a ispitana je hi-kvadrat testom. Utvrđeno je da ne postoje statistički značajne razlike između prostorne koncentracije hrvatskih i slovenskih vikendaša u obalnim naseljima općine $\left(\chi^{2}=0,502, \mathrm{df}=1, \mathrm{p}=0,509\right)$. Odbacivanje te hipoteze podupire zaključak o ravnomjernoj prostornoj distribuciji hrvatskih i slovenskih vikendaša na prostoru općine.

Ako se analizira zastupljenost stambenih jedinica za odmor i rekreaciju u vlasništvu vlasnika iz Hrvatske odnosno Slovenije prema površinskim kategorijama (tablica 3), može se primijetiti da su »slovenske« vikendice ne- 
znatno brojnije u razredu $35,01-60,00 \mathrm{~m}^{2}$, dok su u svim ostalim razredima s obzirom na površinu »hrvatske« vikendice, također neznatno, brojnije.

Tablica 3. Broj vikendica u vlasništvu hrvatskih i slovenskih vlasnika u općini Dobrinj prema površinskim kategorijama $\left(\mathrm{m}^{2}\right) 2013$.

Table 3. The number of second homes in the ownership of Croatian and Slovenian owners in the Municipality of Dobrinj by floor area categories $\left(\mathrm{m}^{2}\right)$ in 2013

\begin{tabular}{lccc}
\hline \multicolumn{1}{c}{ Površina $\left(\mathbf{m}^{\mathbf{2}}\right)$} & $\begin{array}{c}\text { Vlasnici iz } \\
\text { Hrvatske }\end{array}$ & $\begin{array}{c}\text { Vlasnici iz } \\
\text { Slovenije }\end{array}$ & Ukupno \\
\hline$\leq 35,00$ & 184 & 170 & 354 \\
\hline $35,01-60,00$ & 357 & 373 & 730 \\
\hline $60,01-100,00$ & 243 & 199 & 442 \\
\hline $100,01-150,00$ & 50 & 46 & $\mathbf{9 6}$ \\
\hline$>150,00$ & 17 & 15 & $\mathbf{3 2}$ \\
\hline Ukupno & $\mathbf{8 5 1}$ & $\mathbf{8 0 3}$ & $\mathbf{1 6 5 4}$ \\
\hline
\end{tabular}

Izvor: dokumentacija Općine Dobrinj, 2013.

Druga radna hipoteza »Stambene jedinice za odmor i rekreaciju u vlasništvu hrvatskih vikendaša u prosjeku su veće od onih u vlasništvu slovenskih vikendaša « ispitana je t-testom. Nije utvrđena statistički značajna razlika u površini »hrvatskih « $\mathrm{i}$ »slovenskih « vikendica u općini $(\mathrm{t}=1,469$, $\mathrm{df}=1632,58, \mathrm{p}=0,144)$. Prosječna veličina vikendica $\mathrm{u}$ cijelome analiziranom uzorku iznosi $57,51 \mathrm{~m}^{2}$, pri čemu je prosječna veličina »hrvatske« vikendice $58,70 \mathrm{~m}^{2}$, a »slovenske« $56,24 \mathrm{~m}^{2} .{ }^{6}$ Može se zaključiti da minimalna evidentirana razlika proizlazi iz nešto veće brojnosti »hrvatskih « vikendica u ukupnom uzorku te se ta radna hipoteza odbacuje.

Žive li hrvatski vikendaši bliže svojim vikendicama u općini Dobrinj od slovenskih? Kada se razmotri brojnost hrvatskih i slovenskih vikendaša

6 Podaci o prosječnoj veličini vikendica u općini Dobrinj na temelju analize podataka općinske dokumentacije 2013. $\left(57,51 \mathrm{~m}^{2}\right)$ te iz Popisa stanovništva, kućanstava i stanova 2011. godine $\left(61,19 \mathrm{~m}^{2}\right)$ gotovo se u potpunosti poklapaju s prosječnom površinom stana za odmor i rekreaciju u Hrvatskoj prema Popisu stanovništva, kućanstava i stanova 2001. godine (56,93 m²) (Miletić, 2011; Opačić, 2012). U usporedbi s popisnim podacima iz 2011. prosječna površina vikendice u općini $\left(61,19 \mathrm{~m}^{2}\right)$ tek je neznatno manja od hrvatskoga prosjeka $\left(60,65 \mathrm{~m}^{2}\right)$. Nešto manja prosječna površina vikendica u općini 2013. $(57,51$ $\left.\mathrm{m}^{2}\right)$, odnosno 2011. $\left(61,19 \mathrm{~m}^{2}\right)$ u usporedbi s kvadraturom stambenih jedinica za odmor i rekreaciju u Primorsko-goranskoj županiji 2011. $\left(63,21 \mathrm{~m}^{2}\right)$, govori u prilog tezi da je zbog blizine mjesta stalnoga prebivališta, u općini podjednako zastupljena upotreba vikendica vikendima i kraćim praznicima kao i tijekom godišnjeg odmora. Naime u udaljenijim i slabije dostupnim receptivnim vikendaškim područjima hrvatskoga priobalja u strukturi vikendica s obzirom na površinu prevladavaju veće stambene jedinice (Opačić, 2012). 
prema razredima s obzirom na najkraću cestovnu (kilometarsku) udaljenost između naselja stalnoga stanovanja i receptivnoga vikendaškog naselja (tablica 4), razvidno je da su »hrvatske« vikendice u većini u razredima do 100 km (zbog brojnih vikendaša iz Rijeke i riječke aglomeracije), 150,01 $200,00 \mathrm{~km}$ (zbog brojnih vikendaša iz Zagreba i zagrebačke aglomeracije) te više od 250 km (zbog većeg broja emitivnih središta vikendaške potražnje na tim udaljenostima, primjerice čitava Slavonija; u taj izotelni razred ulazi tek krajnji sjeveroistok Slovenije - regije Podravska, s Mariborom i njegovom aglomeracijom, te Pomurska). Slovenci pak prevladavaju u razredu 100,01 - 150,00 km (zbog brojnih vikendaša iz Ljubljane i ljubljanske aglomeracije, kao i jugozapadnoga dijela Središnje Slovenije) te 200,01 - 250,00 km (zbog velikog broja vikendaša iz Celja i ostalih naselja Savinjske regije).

Tablica 4. Broj vikendica u vlasništvu hrvatskih i slovenskih vlasnika u općini Dobrinj prema udaljenosti $(\mathrm{km})$ od naselja stalnog prebivališta 2013.

Table 4. The number of second homes in the ownership of Croatian and Slovenian owners in the Municipality of Dobrinj in 2013 by the distance $(\mathrm{km})$ from the place of permanent residence

\begin{tabular}{lccc}
\hline Udaljenost $\mathbf{( k m )}$ & $\begin{array}{c}\text { Vlasnici iz } \\
\text { Hrvatske }\end{array}$ & $\begin{array}{c}\text { Vlasnici iz } \\
\text { Slovenije }\end{array}$ & Ukupno \\
\hline$\leq 100,00$ & 185 & 29 & $\mathbf{2 1 4}$ \\
\hline $100,01-150,00$ & 54 & 173 & $\mathbf{2 2 7}$ \\
\hline $150,01-200,00$ & 396 & 334 & $\mathbf{7 3 0}$ \\
\hline $200,01-250,00$ & 88 & 163 & $\mathbf{2 5 1}$ \\
\hline$>250,00$ & 128 & 104 & $\mathbf{2 3 2}$ \\
\hline Ukupno & $\mathbf{8 5 1}$ & $\mathbf{8 0 3}$ & $\mathbf{1 6 5 4}$ \\
\hline
\end{tabular}

Izvor: dokumentacija Općine Dobrinj, 2013.; Google Maps, https://maps.google.hrl maps?hl=hrEtab=wl

Dakle očigledno je da razlike u vikendaškoj potražnji s obzirom na doseg vikendaških kretanja i nisu snažnije izražene. Ipak, ispitivanje treće radne hipoteze »Hrvatski vikendaši u odnosu na slovenske žive u prosjeku u emitivnim naseljima bližim receptivnim naseljima u općini Dobrinj « t-testom $(\mathrm{t}=4,695, \mathrm{df}=1652, \mathrm{p}=0,001)$ pokazalo je da statistički značajne razlike između kontingenata vikendaša iz Hrvatske i Slovenije ipak postoje. Utvrđeno je da hrvatski vikendaši u prosjeku žive bliže receptivnim naseljima u op- 
ćini Dobrinj ( $\mathrm{M}=2,91, \mathrm{SD}=1,28)$ u odnosu na slovenske $(\mathrm{M}=3,17, \mathrm{SD}=1,03){ }^{7}$ Velika dominacija vikendaša iz Primorsko-goranske županije, što uvelike ponderira uzorak $\mathrm{u}$ »najbližemu « izotelnom razredu, zaslužna je za prihvaćanje te hipoteze. Ostaje upitno koliko je među evidentiranim vikendicama u vlasništvu vikendaša iz Primorsko-goranske županije de facto objekata za stalno stanovanje, koji su nasljeđivanjem od starijih generacija de iure postali stanovi za odmor i rekreaciju.

Dolaze li hrvatski vikendaši u prosjeku iz većih naselja stalnih prebivališta nego slovenski? Pregled broja vikendica u razredima s obzirom na broj stanovnika naselja stalnih prebivališta prema recentnim podacima o broju stanovnika jasno vodi potvrdnom odgovoru (tablica 5).

Tablica 5. Broj vikendica u vlasništvu hrvatskih i slovenskih vlasnika u općini Dobrinj 2013. prema veličini naselja stalnog prebivališta

Table 5. The number of second homes in the ownership of Croatian and Slovenian owners in the Municipality of Dobrinj in 2013 by the size of the settlements of permanent residence

\begin{tabular}{lccc}
\hline $\begin{array}{c}\text { Broj stanovnika } \\
\left(\begin{array}{c}\text { 2011. u RH, 2013. } \mathbf{u} \\
\text { SLO) }\end{array}\right.\end{array}$ & $\begin{array}{c}\text { Vlasnici iz } \\
\text { Hrvatske }\end{array}$ & $\begin{array}{c}\text { Vlasnici iz } \\
\text { Slovenije }\end{array}$ & Ukupno \\
\hline$\leq 2000$ & 109 & 196 & $\mathbf{3 0 5}$ \\
\hline $2001-15.000$ & 159 & 305 & $\mathbf{4 6 4}$ \\
\hline $15.001-50.000$ & 100 & 86 & $\mathbf{1 8 6}$ \\
\hline $50.001-100.000$ & 38 & 23 & $\mathbf{6 1}$ \\
\hline$>100.000$ & 445 & 193 & $\mathbf{6 3 8}$ \\
\hline Ukupno & 851 & 803 & $\mathbf{1 6 5 4}$ \\
\hline
\end{tabular}

Izvor: dokumentacija Općine Dobrinj 2013., Popis stanovništva, kućanstava i stanova 2011., 2013.; Prebivalstvo - izbrani kazalniki, naselja, Slovenija, letno, 2013.

Naime uočljiva je izrazita dominacija »Slovenaca« među vikendašima koji žive u naseljima do 2000 stanovnika, kao i u naseljima između 2000 i 15.000 stanovnika, dok u ostala tri razreda (15.001 - 50.000 stanovnika, 50.001 - 100.000 stanovnika te više od 100.000 stanovnika) slabije ili jače naglašeno prevladavaju »Hrvati«. Četvrta radna hipoteza »Naselja stalnih

7 Budući da su izvorni podaci o udaljenosti stalnih prebivališta vikendaša od receptivnih naselja u općini Dobrinj tijekom unosa kodirani u izotelne razrede vidljive u tablici 4 (pri čemu je udaljenost $\leq 100,00 \mathrm{~km}$ označena brojem 1, a udaljenost $>250,00 \mathrm{~km}$ brojem 5), aritmetičke sredine odražavaju pripadnost izotelnome razredu. 
prebivališta hrvatskih vikendaša u prosjeku su veća od naselja stalnih prebivališta slovenskih vikendaša « stoga se nakon što je ispitana t-testom kojim su ustanovljene statistički značajne razlike $(\mathrm{t}=13,393, \mathrm{df}=1651, \mathrm{p}=0,001)$ može prihvatiti. Utvrđeno je da su naselja stalnih prebivališta hrvatskih vikendaša u prosjeku veća $(M=3,65, S D=1,56)$ od naselja stalnih prebivališta slovenskih vikendaša $(\mathrm{M}=2,64, \mathrm{SD}=1,49) .{ }^{8}$

Iz svega do sada prezentiranoga jasno se razabire da je Zagreb sa svojom aglomeracijom vodeći prostor hrvatske vikendaške potražnje za vikendicama u općini Dobrinj (51,94\% hrvatskih vikendaša u općini Dobrinj ima prebivalište u Gradu Zagrebu i Zagrebačkoj županiji), dok je Ljubljana s pripadajućom aglomeracijom primarno slovensko emitivno vikendaško područje $(46,08 \%$ slovenskih vikendaša u općini ima prebivalište u Središnjoj Sloveniji) (tablica 6).

Tablica 6. Zastupljenost vlasnika iz Grada Zagreba i Zagrebačke županije u kontingentu hrvatskih vikendaša te vlasnika iz Središnje Slovenije u kontingentu slovenskih vikendaša u općini Dobrinj 2013.

Table 6. Share of second home owners from the City of Zagreb and the Zagreb County in Croatian quota, and second home owners from Central Slovenia in Slovenian quota in the Municipality of Dobrinj in 2013

\begin{tabular}{lcc|cc}
\hline Naselje & $\mathbf{N}$ & $\begin{array}{c}\text { Vlasnici iz Grada Zagreba i } \\
\text { Zagrebačke županije } \\
\text { hrvatskih vlasnika (\%) }\end{array}$ & $\begin{array}{c}\text { Vlasnici iz Središnje } \\
\text { Slovenije }\end{array}$ \\
\cline { 2 - 5 } & 57 & 46,72 & 63 & $\begin{array}{c}\text { Udio u kontingentu } \\
\text { slovenskih vlasnika } \\
\mathbf{( \% )}\end{array}$ \\
\hline Čižići & 61 & 48,03 & 75 & 36,63 \\
\hline Klimno & 2 & 40,00 & 1 & 40,76 \\
\hline Rudine & 14 & 36,84 & 40 & 33,33 \\
\hline Soline & 162 & 69,83 & 32 & 50,63 \\
\hline Šilo & $\mathbf{2 9 6}$ & $\mathbf{5 6 , 4 9}$ & $\mathbf{2 1 1}$ & $\mathbf{4 1 , 5 4}$ \\
\hline Obalna naselja & 24 & 40,00 & 5 & 83,33 \\
\hline Dobrinj & & &
\end{tabular}

8 Budući da su izvorni podaci o veličini naselja stalnog prebivališta vikendaša tijekom unosa kodirani u razrede vidljive u tablici 5 (pri čemu su naselja $\leq 2000$ stanovnika označena brojem 1, a naselja > 100.000 stanovnika brojem 5), aritmetičke sredine odražavaju pripadnost veličinskome razredu. 


\begin{tabular}{|c|c|c|c|c|}
\hline \multirow{2}{*}{ Naselje } & \multicolumn{2}{|c|}{$\begin{array}{l}\text { Vlasnici iz Grada Zagreba i } \\
\text { Zagrebačke županije }\end{array}$} & \multicolumn{2}{|c|}{$\begin{array}{c}\text { Vlasnici iz Središnje } \\
\text { Slovenije }\end{array}$} \\
\hline & $\mathbf{N}$ & $\begin{array}{c}\text { Udio u kontingentu } \\
\text { hrvatskih vlasnika }(\%)\end{array}$ & $\mathbf{N}$ & $\begin{array}{c}\text { Udio u kontingentu } \\
\text { slovenskih vlasnika } \\
(\%)\end{array}$ \\
\hline Gabonjin & 19 & 67,86 & 5 & 100,00 \\
\hline Gostinjac & 11 & 55,00 & 10 & 50,00 \\
\hline Hlapa & 5 & 41,67 & 60 & 54,05 \\
\hline Klanice & 2 & 50,00 & 0 & 0,00 \\
\hline Kras & 18 & 38,30 & 2 & 100,00 \\
\hline Polje & 45 & 53,57 & 39 & 53,42 \\
\hline Rasopasno & 10 & 28,57 & 3 & 60,00 \\
\hline Sužan & 5 & 50,00 & 3 & 37,50 \\
\hline Sv. Ivan Dobrinjski & 1 & 25,00 & 1 & 50,00 \\
\hline Sv. Vid Dobrinjski & 2 & 28,57 & 0 & 0,00 \\
\hline Tribulje & 0 & 0,00 & 1 & 33,33 \\
\hline Žestilac & 2 & 50,00 & 24 & 53,33 \\
\hline Županje & 2 & 20,00 & 6 & 66,67 \\
\hline Naselja u unutrašnjosti & 146 & 44,65 & 159 & 53,90 \\
\hline UKUPNO & 442 & 51,94 & 370 & 46,08 \\
\hline
\end{tabular}

Izvor: dokumentacija Općine Dobrinj 2013.

Među hrvatskim vikendašima veći udio vlasnika stanova za odmor i rekreaciju s područja Grada Zagreba i Zagrebačke županije u odnosu na vlasnike iz drugih dijelova Hrvatske registriran je u obalnim naseljima $(56,49 \%)$ negoli u naseljima u unutrašnjosti (44,65\%). Naselje u općini s najvećim udjelom »Zagrepčana « $\mathrm{u}$ hrvatskoj vikendaškoj populaciji jest Šilo $(69,83 \%)$, a slijede ga Gabonjin (67,86\%), Gostinjac (55,00\%) i Polje (53,57\%). U kontingentu slovenskih vlasnika vikendica, oni iz Središnje Slovenije u odnosu na ostale »Slovence« izrazitije prevladavaju u naseljima u unutrašnjosti (53,90\%) negoli u obalnim naseljima (41,54\%). Najveća zastupljenost "Ljubljančana « među slovenskim vikendašima evidentirana je u Hlapi (54,05\%), Polju (53,42\%), Žestilcu (53,33\%) te u Solinama (50,63\%). Kako bi se izbjeglo zaključivanje pod utjecajem »zakona malih brojeva«, ni u hrvatskom ni u slovenskom kontingentu vikendaša nisu komentirana naselja $s$ manje od dvadeset vikendica bilo u vlasništvu hrvatskih, bilo u vlasništvu slovenskih vikendaša. 
Je li Zagreb jače emitivno središte vikendaške potražnje za vikendicama u općini Dobrinj među hrvatskim vikendašima od Ljubljane (analizirana je regija Središnja Slovenija) među slovenskima? Peta radna hipoteza ovoga istraživanja glasi: »Naglašenija je dominacija Grada Zagreba i Zagrebačke županije kao vodećega emitivnog područja u kontingentu hrvatskih vikendaša nego Središnje Slovenije (s Ljubljanom) kod slovenskih", a ispitana je hi-kvadrat testom. Ustanovljeno je da postoji statistički značajna razlika $\left(\chi^{2}=5,680, \mathrm{df}=1, \mathrm{p}=0,017\right)$ između prevlasti u vikendaškoj potražnji stanovništva Grada Zagreba i Zagrebačke županije u »hrvatskom « dijelu uzorka u odnosu na značenje stanovništva Središnje Slovenije u »slovenskom« dijelu uzorka. Prihvaćanje te hipoteze govori u prilog tezi o jačoj centralizaciji hrvatske vikendaške potražnje u odnosu na slovensku u općini Dobrinj.

\section{ZAKLJUČAK}

Međunarodna vikendaška kretanja sve su izraženija pojava na hrvatskoj obali i otocima. Među inozemnim vikendašima brojnošću stambenih jedinica za odmor i rekreaciju prednjače vlasnici iz Slovenije. Veliki broj »slovenskih « obiteljskih vikendica izgrađen je u vrijeme zajedničke države, da bi se u posljednjih dvadesetak godina, a osobito nakon smirivanja ratnih i poratnih prilika u široj regiji te istovremenoga približavanja Hrvatske Europskoj uniji i konačnog ulaska Hrvatske u njezino punopravno članstvo proces jačanja vikendaštva nastavio u obliku snažne apartmanizacije. Slovenska vikendaška potražnja tradicionalno je usmjerena ponajviše na prostor sjevernoga hrvatskog primorja, u kojemu se brojnošću vikendica kao poželjno receptivno područje ističe otok Krk, napose općina Dobrinj.

U općini Dobrinj kao dvije najizrazitije zone vikendaštva mogu se identificirati a) najveće općinsko naselje Šilo te b) priobalni pojas zaljeva Soline. Te su dvije zone i u prethodnim razdobljima prednjačile brojem stambenih jedinica povremenoga rekreacijskog stanovanja te se porast koncentracije potražnje u njima nastavio i u recentnom razdoblju. Istraživanjem se u najnovijem razdoblju (2007. - 2013.) utvrdio brži porast broja »slovenskih « vikendica u odnosu na »hrvatske«, pa je danas (2013.) zamjetna podjednaka zastupljenost hrvatskih i slovenskih vlasnika vikendica u općini. Kontinuitet jake slovenske vikendaške potražnje prema tome receptivnom vikendaškom području potiču i slovenska poduzeća koja su na tome području prisutna i kao građevinski investitori.

Kao vodeća emitivna područja vikendaških kretanja prema općini Dobrinj mogu se izdvojiti Grad Zagreb sa Zagrebačkom županijom te Primor- 
sko-goranska županija (s Rijekom) u Hrvatskoj te Središnja Slovenija (s Ljubljanom) i Savinjska regija (Celje) u Sloveniji. To govori u prilog poznatoj činjenici o paralelizmu kvalitetne prometne dostupnosti te povezanosti i snage vikendaških prostornih kretanja. Spomenuta emitivna područja izdvajaju se i kao glavna područja vikendaške potražnje jer je prostor Kvarnera za tamošnje stanovništvo »najbliže more«i do njega se u današnjim uvjetima cestovnoga prometa može stići za približno dva sata vožnje osobnim automobilom. Znatno slabija vikendaška kretanja zabilježena su iz ostalih (pri)obalnih područja Hrvatske i Slovenije, što se može objasniti postojanjem bližih, a istovremeno ne manje atraktivnih receptivnih područja. Iz udaljenijih emitivnih vikendaških prostora Hrvatske (npr. slavonske županije) i Slovenije (Pomurska, Koruška) evidentirana su slabija vikendaška kretanja prema općini Dobrinj.

Glavni cilj ovoga rada jest usporedba prostornih i strukturnih obilježja hrvatskih i slovenskih vikendaških kretanja u receptivnome vikendaškom području na primjeru općine Dobrinj. Ispitivanjem pet radnih hipoteza iskristalizirali su se sljedeći zaključci:

1. Nema izraženije razlike u preferiranju obalnih naselja, odnosno naselja u unutrašnjosti između hrvatskih $i$ slovenskih vikendaša. To govori u prilog tezi da su pretpostavke o velikim razlikama u preferiranju željenog prostora (ambijenta) za rekreaciju između Hrvata i Slovenaca očito ipak prenaglašene. Naime $u$ javnosti se nerijetko ističu razlike $u$ percepciji »obalne« ili »ruralne« idile kod Hrvata odnosno Slovenaca, pri čemu se oblikuju stereotipi kako Hrvati daju prednost stacionarnijem obliku odmora prije svega na moru, dok su Slovenci zagovornici aktivnijeg oblika odmora podjednako preferirajući obalna, planinska i ruralna turističko-rekreacijska područja.

2. Nema značajnije razlike u površini »hrvatskih « $i$ »lovenskih « vikendica. Taj zaključak upućuje na konstataciju da je glavnina stambenih jedinica za odmor i rekreaciju u općini Dobrinj izgrađena u novije vrijeme. Zanemarive razlike u prosječnoj kvadraturi vikendice u općini između vlasnika iz $\mathrm{Hr}$ vatske i Slovenije navode na zaključak da je u recentnoj, apartmanskoj etapi razvoja vikendaštva slovenska potražnja jača od hrvatske te da je veliki udio vikendica u općini izgrađen u posljednjih desetak, petnaestak godina. Naime prema broju vikendica u prethodnim razdobljima (do prvih godina 21. stoljeća) vikendaši iz Hrvatske znatno su nadmašivali vikendaše iz Slovenije. Budući da su vikendice u obliku obiteljske kuće u prosjeku površinom bile veće od apartmana, veća prosječna površina stambene jedinice za odmor i rekreaciju kod »hrvatskih« vikendaša upućivala bi na zaključak da 
$\mathrm{u}$ današnjem kontingentu vikendica $u$ općini prevladavaju one izgrađene prijašnjih godina, a analiza recentnih podataka pokazala je upravo suprotno.

3. Hrvatski vikendaši u odnosu na slovenske žive u prosjeku u emitivnim naseljima bližim receptionim naseljima u općini Dobrinj. Veliki broj vikendica u vlasništvu vlasnika iz Primorsko-goranske županije znatno ponderira uzorak, pa se može konstatirati da hrvatski vikendaši u odnosu na slovenske u prosjeku žive bliže svojim vikendicama u općini Dobrinj. Pitanje je međutim koliko se objekata registriranih kao stan za odmor i rekreaciju u vlasništvu vlasnika iz Primorsko-goranske županije uistinu rabi kao vikendica. S druge strane, značajni broj stanova registriranih kao stalno nastanjeni dio stambenoga fonda u općini upotrebljava se kao vikendice zbog ostvarivanja određenih beneficija koje proizlaze iz statusa otočnoga stanovništva (npr. besplatan prijelaz preko Krčkog mosta). To upućuje na nužnost realnijeg evidentiranja vikendica, što je izazov s kojim se susreću brojne države na svijetu.

4. Naselja stalnih prebivališta hrvatskih vikendaša u prosjeku su veća od naselja stalnih prebivališta slovenskih vikendaša. Na taj zaključak ponajviše je utjecala veličina populacije Zagreba, jer grad takve veličine u Sloveniji ne postoji. No prevlast slovenskih vikendaša među vikendašima iz naselja do 15.000 stanovnika jasno upućuje na razlike u snazi vikendaške potražnje iz selâ i manjih naselja (do 2000 stanovnika), kao i iz malih gradova, s funkcijom lokalnih centara u mreži centralnih naselja. Iz toga se mogu razabrati i razlike u vikendaškim potrebama stanovništva selâ i manjih naselja, kao i lokalnih centara u Hrvatskoj i Sloveniji. Budući da glavnina vikendaške potražnje tradicionalno dolazi iz gradova, odnosno većih naselja, čini se opravdanim četvrti zaključak ovoga istraživanja staviti u kontekst kvalitetnije funkcionalne opremljenosti slovenskih sela i malih gradova u odnosu na hrvatske, što proizlazi iz razlika u obilježjima urbanizacije. Naravno da je pritom važan element i kupovna moć stanovništva, koja je kod stanovništva slovenskih sela i malih gradova osjetno veća nego kod hrvatskih.

5. Naglašenija je dominacija Grada Zagreba i Zagrebačke županije kao vodećega emitivnog područja u kontingentu hrvatskih vikendaša nego Središnje Slovenije (s Ljubljanom) kod slovenskih. Taj nalaz neminovno upućuje na izraženiji monocentrični razvoj u Hrvatskoj, za razliku od naglašenije policentrične regionalne strukture Slovenije. Budući da je Hrvatska država s nepravilnijim urbanim sustavom od Slovenije, u kojemu je izrazito istaknut indeks urbane primarnosti Zagreba ispred svih drugih gradova, ne iznenađuje činjenica da emitivna vikendaška regija jezgre u Hrvatskoj (Grad Zagreb i Zagrebač- 
ka županija) jače prevladava u strukturi hrvatskih vikendaša od emitivne vikendaške regije jezgre u Sloveniji (Središnja Slovenija s Ljubljanom).

Prilikom interpretacije zaključaka o sličnostima i razlikama hrvatskih i slovenskih vikendaških kretanja valja imati na umu da je istraživanje obuhvatilo vikendaše u samo jednoj općini. Za dobivanje potpunije slike bilo bi neophodno analizi pridružiti i kvalitativne podatke dobivene anketiranjem hrvatskih i slovenskih vikendaša u hrvatskom priobalju te detaljno analizirati razlike $u$ elementima prostorne transformacije vikendaškoga pejzaža receptivnoga vikendaškog područja pod utjecajem hrvatskih odnosno slovenskih vikendaša.

\section{Zahvala}

Najljepše zahvaljujem na pomoći administrativnom osoblju Općine Dobrinj koje mi je ustupanjem podataka o površini vikendica i stalnom prebivalištu njihovih vlasnika omogućilo ovo istraživanje.

\section{LITERATURA}

Bell, M. i Ward, G. (2000). Comparing temporary mobility with permanent migration, Tourism Geographies, 2 (1): 87-107, doi: 10.1080/146166800363466.

Božić, S. (2001). Posljednja avantura: umirovljeničke migracije, klima i »ugodnosti«, Migracijske i etničke teme, 17 (4): 311-326.

Casado-Diaz, M. A. (2004). Second homes in Spain, u: C. M. Hall i D. K. Müller (ur.). Tourism, mobility and second homes: between elite landscape and common ground. Clevedon - Buffalo - Toronto: Channel View Publications, 215-232.

Curić, Z. (2002). Slovenski turisti u Hrvatskoj, Hrvatski geografski glasnik, 64: 21-32.

Gršković, J. V. (2004). Polje u dvadesetom stoljeću. Krk - Rijeka: Povijesno društvo otoka Krka - »Adamić«.

Mihaljek, D. (2005). Slobodno kretanje kapitala, tržište nekretnina i turizam: blagodat ili nevolja za Hrvatsku na putu u Europsku uniju?, u: K. Ott (ur.). Pridruživanje Hrvatske Europskoj uniji: ususret izazovima pregovora. Zagreb: Institut za javne financije, 181-222.

Miletić, G.-M. (2011). U potrazi za drugim prostorom: sociologijski aspekti sekundarnog stanovanja u Hrvatskoj. Zagreb: Institut društvenih znanosti Ivo Pilar.

Müller, D. K. (2002). German second home owners in Sweden: some remarks on the tourism - migration - nexus, Revue Européene des Migrations Internationales, 18 (1): 67-86.

Nejašmić, I. (2005). Demogeografija: stanouništvo u prostornim odnosima i procesima. Zagreb: Školska knjiga. 
Nejašmić, I. (2008). Stanovništvo Hrvatske: demografske studije i analize. Zagreb: Hrvatsko geografsko društvo.

Novosel-Žic, P. (1980-1981). Kuće za odmor na otoku Krku, Radovi GO, 15-16: 13-23.

Novosel-Žic, P. (1987). Otok Krk od trajekta do mosta: (socijalno-geografska transformacija). Krk - Zagreb: Povijesno društvo otoka Krka - Savez geografskih društava Hrvatske.

Novosel-Žic, P. (1996). Dobrinjsko područje: s posebnim osvrtom na demografski razvoj, Krčki zbornik, 35: 19-44.

Opačić, V. T. (2002). Turizam kao faktor preobrazbe općine Dobrinj, Hrvatski geografski glasnik, 64: 33-54.

Opačić, V. T. (2008). Vikendice na otoku Krku - prostorni raspored i strukturna obilježja vlasnika, Geoadria, 13 (1): 41-80.

Opačić, V. T. (2009a). Fizionomske implikacije vikendaštva u receptivnim naseljima primjer Malinske na otoku Krku, Geoadria, 14 (2): 273-310.

Opačić, V. T. (2009b). Recent characteristics of the second home phenomenon in the Croatian littoral, Hrvatski geografski glasnik, 71 (1): 33-66.

Opačić, V. T. (2010). Jesu li vikendaška kretanja oblik prostorne cirkulacije ili migracije?, u: A. Lukić (ur.). Geografija.hr offline: 2007-2009. Zagreb: Hrvatsko geografsko društvo, 22-26.

Opačić, V. T. (2011). Prijedlog koncepta istraživanja vikendaštva u receptivnome vikendaškom području, Hrvatski geografski glasnik, 73 (1): 181-200.

Opačić, V. T. (2012). Vikendaštvo u hrvatskom priobalju: jučer, danas, sutra. Zagreb: Hrvatska sveučilišna naklada.

Turk, H. i Mirković, D. (1993). Trajekti u turističkoj valorizaciji Kvarnerskih otoka, Geografski glasnik, 55: 135-149.

Williams, A. M. i Hall, C. M. (2000a). Guest editorial: Tourism and migration, Tourism Geographies, 2 (1): 2-4, doi: 10.1080/146166800363411.

Williams, A. M. i Hall, C. M. (2000b). Tourism and migration: new relationship between production and consumption, Tourism Geographies, 2 (1): 5-27, doi: 10.1080/146166800363420.

Williams, A. M., King, R., Warnes, T. i Patterson, G. (2000). Tourism and international retirement migration: new forms of an old relationship in southern Europe, Tourism Geographies, 2 (1): 28-49, doi: 10.1080/146166800363439.

Williams, D. R. i Kaltenborn, B. P. (2001). Leisure place and modernity: the use and meaning of recreational cottages in Norway and the USA, u: D. Crouch (ur.). Leisurel tourism geographies. London - New York: Routledge, 214-230.

Zelić, D. (1993). Nastanak urbanih naselja na otoku Krku, Radovi Instituta za povijest umjetnosti, 17 (2): 7-17.

\section{IZVORI}

Dokumentacija Općine Dobrinj, 2001., 2007. i 2013. godine.

Popis stanovništva, kućanstava i stanova 2011., Državni zavod za statistiku, Zagreb, 2013., http://www.dzs.hr/.

Prebivalstvo-izbrani kazalniki, naselja, Slovenija, letno, Statistični urad Republike Slovenije, Ljubljana, 2013., http://pxweb.stat.si/. 


\title{
The Comparison between Croatian and Slovenian Second Home Mobilities on Croatian Islands: the Case Study of the Municipality of Dobrinj
}

\author{
Vuk Tvrtko Opačić
}

\begin{abstract}
SUMMARY
Second home owners from Slovenia prevail in the structure of international second home mobilities on Croatian coast and islands. The same phenomenon can be seen in the example of Istria and the Kvarner region, particularly on the island of Krk, due to proximity and traffic accessibility. The main goal of this research is to compare spatial and structural characteristics between Croatian and Slovenian second home mobilities in a receiving second home area. The Municipality of Dobrinj was chosen as a representative example of the receiving second home region due to an almost equal share of Croatian and Slovenian owners. It is also the municipality with the biggest number of Slovenian second home owners on the island of Krk. Methodology of the research relies on analysis of referral literature, statistical analysis of the quantitative population census data and the data from the administrative archive of the Municipality of Dobrinj referring to floor area of second homes and the place of permanent residence of the owners according to Croatian counties and Slovenian statistical regions, both NUTS-3 level. Data analysis included descriptive statistics, Chi-square test and t-test in identifying differences between Croatian and Slovenian sub-sample. The City of Zagreb, Primorje-Gorski Kotar County and Zagreb County in Croatia, and Central Slovenia and Savinja Region in Slovenia were identified as main emissive second home regions. Conclusions are as follows: there are no statistically significant differences in preferences towards coastal/inner settlements between Croatian and Slovenian owners; there are no statistically significant differences in floor areas of "Croatian" and "Slovenian" second homes; Croatian owners live in emissive settlements closer to receptive settlements in the Municipality of Dobrinj comparing to Slovenian owners; the settlements of permanent residence of Croatian owners are on average larger than those of Slovenian owners; and that the City of Zagreb and Zagreb County are more dominant as main emissive regions in the Croatian quota than Central Slovenia (with Ljubljana) in Slovenian.
\end{abstract}

KEY WORDS: second home use, international second home mobilities, recreation, the Municipality of Dobrinj, the island of Krk, Croatia 